\title{
Relationship between Knowledge and Attitude of the Elderly in Handwashing as an Effort to Prevent Covid-19
}

\author{
Desi Meliana Gultom ${ }^{1}$, Evi Erianty Hasibuan ${ }^{2}$, Elpiana Sari ${ }^{3}$, Fitria Lely Effina Batubara ${ }^{4}$ \\ ${ }_{2,3,3}$ Lecturer of Institut Teknologi dan Kesehatan Sumatera Utara
}

\begin{tabular}{|c|c|}
\hline Article Info & ABSTRACT \\
\hline Article history: & \multirow{8}{*}{$\begin{array}{l}\text { Data updated by the Indonesian Ministry of Health on February 17, 2020, } \\
\text { WHO has designated Covid-2019 as a Public Health Emergency of } \\
\text { International Concern (PHEIC) due to a significant increase in cases and } \\
\text { confirmed cases in several other countries. The New England Journal of } \\
\text { Medicine (NEJM) on January } 29,2020 \text { summarized the first } 425 \text { cases } \\
\text { recorded in Wuhan. The data show that the mean age of the patients was } 59 \\
\text { years, with a range of } 15 \text { to } 89 \text { years. This study aims to determine the } \\
\text { relationship between knowledge and the attitude of the elderly in washing } \\
\text { their hands as an effort to prevent Covid-19. This type of research is analytic } \\
\text { observational with cross sectional design. The research sample was } 21 \\
\text { elderly people. The data analysis used was univariate analysis, bivariate } \\
\text { analysis and multivariate analysis with chi square test with p value }<0.05 \text {. } \\
\text { There is a relationship between knowledge and attitude with elderly hand } \\
\text { washing as an effort to prevent COVID-19 in } 2020 \text { with a p value }<0.05 \text {. It } \\
\text { is hoped that all parties can cooperate in disseminating health protocols, } \\
\text { especially hand washing and the provision of hand washing facilities as a } \\
\text { form of COVID-19 prevention efforts. }\end{array}$} \\
\hline Received December 03, 2021 & \\
\hline Revised December 25, 2021 & \\
\hline Accepted January 14, 2022 & \\
\hline Corresponding Author: & \\
\hline $\begin{array}{l}\text { Desi Meliana Gultom } \\
\text { Lecturer, } \\
\text { Institut Teknologi dan }\end{array}$ & \\
\hline $\begin{array}{l}\text { Kesehatan Sumatera Utara, } \\
\text { Padangsidimpuan, Indonesia }\end{array}$ & \\
\hline $\begin{array}{l}\text { Email: } \\
\text { desimelianagultom@gmail.com }\end{array}$ & \\
\hline
\end{tabular}

Keywords:

Knowledge; Attitude; Washing hands; Covid-19

This article is licensed under a Creative Commons AttributionShareAlike 4.0 International License..

\section{INTRODUCTION}

On December 31, 2019, the WHO China Country Office reported a case of pneumonia of unknown etiology in Wuhan City, Hubei Province, China. On January 7, 2020, China identified the pneumonia of unknown etiology as a new type of coronavirus (novel coronavirus). In early $2020 \mathrm{NCP}$ began to become a global pandemic and became a health problem in several countries outside the PRC. According to the World Health Organization (WHO), cluster cases of pneumonia with unclear etiology in Wuhan City have become a global health problem. The spread of this epidemic continued to grow until it was finally discovered that the cause of this pneumonia cluster was the Novel Coronavirus. This pandemic continues to grow until there are reports of new deaths and cases outside China. On January 30, 2020, WHO declared COVID-19 a Public Health Emergency of International Concern (PHEIC). On February 12, 2020, WHO officially designated this novel coronavirus disease in humans as Coronavirus Disease (COVID-19). COVID-19 is caused by SARS-COV2, which belongs to the same large family of coronaviruses that caused SARS in 2003, only with a different type of virus. Symptoms are similar to SARS, but the death rate for SARS (9.6\%) is higher than for COVID-19 (currently less than 5\%), although the number of cases of COVID-19 is much higher than that of SARS. COVID-19 also has a wider and faster spread to several countries than SARS. [1]

On January 27, 2020 WHO published the development of cases of the novel coronavirus (COVID-19), namely the total number of confirmed cases was 2798 cases, 2761 cases of which were reported from China (spread in 30 regions), a total of 80 deaths (CFR 2.89\%) were reported. all of which occurred in China, confirmed cases were reported in 11 countries, as many as 37 cases, most of which had a travel history from the city of Wuhan, China and 2 cases identified with no travel history from the city of wuhan, namely Australia and Vietnam. In 
Virtnam, this is close contact with a confirmed case of COVID-19 and has a travel history from the city of Wuhan. This can show that this covid-19 can be a case of human-to-human transmission in one family. [2]

Data updated by the Indonesian Ministry of Health on February 17, 2020, WHO has designated 2019 $\mathrm{nCoV}$ as a Public Health Emergency of International Concern (PHEIC) since January 30, 2020 due to a significant increase in cases and confirmed cases in Indonesia. several other countries. There are 15 countries, namely China, Singapore, Japan, Republic of Korea, Malaysia, Vietnam, Thailand, United States of America, Germany, France, UK, Spain, United Arab Emirates, Australia, and Egypt. Meanwhile, other countries only report imported cases from China (have a history of traveling to China) and there has been no local transmission in their country. This list of countries can change every day following the development of data and information obtained. Confirmed cases in China have spread to 34 regions including confirmed cases in Hong Kong SAR (57 Confirmed Cases and 1 death), Macau SAR (10 Confirmed Cases), and Taipei (20 Confirmed Cases) with $82 \%$ of confirmed cases originating from Hubei Province. Of the 794 cases reported in 25 countries outside China, 26 cases were detected without symptoms and 156 cases in 14 countries had no history of travel to China. [2]

Current research shows that the homology between COVID-19 and the DNA characteristics of bat-SARS coronaviruses is more than $85 \%$ similar. When cultured in vitro, COVID-19 can be found in human respiratory epithelial cells after 96 hours. Meanwhile, it took about 6 days to isolate and culture vero E6 and Huh-7 cell lines. The lungs are the organs most affected by COVID-19, as the virus accesses host cells via the enzyme ACE2, which is most abundant in type II alveolar cells of the lungs. The virus uses a special surface glycoprotein, called a "spike", to link to ACE2 and enter the host cell. The density of ACE2 in each tissue correlates with the severity of disease in that tissue and some experts argue that decreased ACE2 activity may be protective. And as alveolar disease progresses, respiratory failure is possible and death is possible. [1]

Epidemiological characteristics, namely someone who has symptoms of fever $\left(\geq 38^{\circ} \mathrm{C}\right)$ or has a history of fever or ARI without pneumonia. In addition, someone who has a history of travel to an infected country in the last 14 days before symptoms appear. The mechanism of transmission of COVID-19 is mainly transmitted by aerosol droplets of patients and through direct contact. Aerosols may be transmitted when people have direct contact with sufferers for too long. The aerosol concentration in a relatively closed room will be higher so that transmission will be easier. [3]

In order to control the rapid transmission of the Covid-19 virus, all members of the community must unite, work together with health workers who are the "last bastion of defense". In dealing with the spread of COVID-19, the community is at the forefront-medical and other health workers helping community members who are stricken with the disease. Therefore, people must understand, understand very well what they have to do. [3]

Case study Li et al. published in the New England Journal of Medicine (NEJM) on January 29, 2020, summarizes the first 425 cases recorded in Wuhan. The data show that the mean age of the patients was 59 years, with a range of 15 to 89 years. Thus, they reported no clinical cases in children under 15 years of age. There was no significant gender difference (56\% male). Clinical and epidemiological data from the Chinese CDC and on 72,314 case records (confirmed, suspected, diagnosed, and asymptomatic cases) were shared in the Journal of the American Medical Association (JAMA) (February 24, 2020), providing an important illustration of the epidemiological curve of the Chinese outbreak. There were $62 \%$ of confirmed cases, including $1 \%$ of cases asymptomatic, but laboratory positive (viral nucleic acid test). Furthermore, the overall case fatality rate (in confirmed cases) was $2.3 \%$. Of note, fatal cases were mainly elderly patients, particularly those aged 80 years (approximately 15\%), and 70 to 79 years $(8.0 \%)$. Approximately half $(49.0 \%)$ of critically ill patients with pre-existing comorbidities such as cardiovascular disease, diabetes, chronic respiratory disease, and oncological disease, died. While $1 \%$ of patients were 9 years of age or younger, no fatal cases occurred in this group. [2]

Based on the available evidence, COVID-19 is transmitted through close contact and droplets, not through airborne transmission. The people most at risk of infection are those who are in close contact with COVID-19 patients or who care for COVID-19 patients. Prevention and mitigation measures are the key to implementation in health and community services, one of which is washing hands.

Based on the problems above, researchers are interested in knowing how the relationship between knowledge and attitudes of the elderly in washing hands as an effort to prevent covid-19 in the village of Tahalak, Kec. Batang Angkola Kab. South Tapanuli in 2020.

\section{METHOD}

This type of research is an analytic observational study with a research design using a cross sectional approach, which is to find a relationship between the level of knowledge and attitudes with hand washing behavior where this study only makes observations once. The population in this study were all elderly people in Tahalak Village, Batang Angkola, South Tapanuli as many as 21 people with a total population sample technique.

This study uses primary data types. Data collection tools used in the study were questionnaires and questionnaires. In this study, the researcher used a closed written questionnaire, which is a questionnaire whose answers have been provided so that the respondents just have to choose. For knowledge consisting of 20 questions about hand washing, the attitude of respondents in washing hands using a Likert scale, namely Strongly Agree (SS) gets a score of 5, Agree (S) gets a score of 4, Doubtful (R) gets a score of 3, Disagree (TS) got a score of 2, and Int Jou of PHE 
Strongly Disagree (STS) got a score of 1 . The data collection technique in this study was carried out on February 30, 2020 in the Tahalak village, Batang Angkola District, South Tapanuli Regency. Data analysis was used with univariate analysis presented in the form of a frequency distribution table that included the percentage form and bivariate and multivariate analysis was used to show the relationship between two variables, namely the relationship between knowledge and washing hands and the relationship between attitudes and washing hands.

\section{RESULTS AND DISCUSSION}

\subsection{Result}

The results of the study of the relationship between knowledge and attitudes of the elderly in washing hands as an effort to prevent covid-19 in the Tahalak village with 21 respondents. The results include the following:

Table 1. Frequency Distribution of Knowledge Levels, Attitudes and Washing Hands in the Elderly

\begin{tabular}{llcc}
\hline No & \multicolumn{1}{c}{ Variable } & Amount & Percentage \\
\hline & Knowledge & & \\
1 & Well & 9 & 42.9 \\
2 & Enough & 3 & 14.3 \\
3 & Not enough & 9 & 42.9 \\
& Amount & 21 & 100 \\
\hline & Attitude & & \\
1 & Support & 11 & 52.4 \\
2 & Does not support & 10 & 47.6 \\
& Amount & 21 & 100 \\
\hline & Hand washing behavior & & 57.1 \\
1 & Yes & 12 & 42.9 \\
2 & No & 9 & 100 \\
\hline
\end{tabular}

The table shows that most of the respondents have good and poor knowledge levels, which are $42.9 \%$. supportive attitude (52.4\%) and the behavior of the majority doing hand washing (57.1\%).

Table 2. Based on Knowledge Level and Attitude with Elderly Hand Washing Behavior in Tahalak Village in 2020

\begin{tabular}{|c|c|c|c|c|c|}
\hline \multirow{3}{*}{ Variable } & \multicolumn{5}{|c|}{ Hand Washing Behavior } \\
\hline & \multicolumn{2}{|c|}{ yes } & \multicolumn{2}{|c|}{ no } & \multirow[t]{2}{*}{ p-value } \\
\hline & $\mathbf{n}$ & $\%$ & $\mathbf{n}$ & $\%$ & \\
\hline Knowledge & & & & & 0.01 \\
\hline Well & 8 & 38.1 & 1 & 4.8 & \\
\hline Enough & 3 & 14.3 & 0 & 0 & \\
\hline Not enough & 1 & 4.8 & 8 & 38.1 & \\
\hline Attitude & & & & & 0.01 \\
\hline Support & 10 & 47.6 & 1 & 4.8 & \\
\hline Does not support & 2 & 9.5 & 8 & 38.1 & \\
\hline
\end{tabular}

From the table above, it can be seen that the majority of respondents have good behavior, the majority have good knowledge, namely $38.1 \%$ and support $47.6 \%$.

From the results of the analysis using the chi square test, it was found that the level of knowledge had a significant relationship with hand washing behavior with a p-value of 0.001 ( $\mathrm{p}$-value $<0.05$ ). This shows that the better the level of knowledge, the better the hand washing behavior of the elderly.

Attitude with early detection behavior of cervical cancer has a significant relationship (p-value 0.001). This shows that the more the elderly have a supportive attitude towards hand washing, the better their behavior towards hand washing will be. 


\subsection{Discussion}

The results showed that most of the respondents had a good and poor level of knowledge, supportive attitude (52.4\%) and the behavior of the majority doing hand washing. Knowledge and attitudes are predisposing behaviors for early detection of cervical cancer. Knowledge affects the elderly in washing their hands as an effort to prevent COVID-19. Low public knowledge about cervical cancer and an unsupportive attitude to washing hands can cause the elderly to be exposed to COVID-19.

The results of the bivariate analysis using the chi square test showed that knowledge and attitudes were significantly related to hand washing behavior with a p-value of knowledge and attitude of 0.001 . These results are in line with AM. Azam's research in 2016 that there is a relationship between hand washing behavior based on the level of knowledge, students with a high level of knowledge have a greater likelihood of washing their hands with soap. Another study by Amar, 2019 there is a significant relationship between knowledge and the habit of washing hands with soap in students of SD Negeri 101893 Bangun Rejo with a p value obtained of 0.000 . There is a relationship between knowledge and attitude with hand washing and the relationship is strong.

\section{CONCLUSION}

There is a relationship between knowledge and attitude with washing the hands of the elderly as an effort to prevent covid-19 in Tahalak Village, Kec. Batang Angkola Kab. South Tapanuli in 2020. It is hoped that all parties will cooperate in promoting health protocols, especially hand washing and providing hand washing facilities as a form of Covid-19 prevention efforts.

\section{ACKNOWLEDGEMENTS}

Thank you to all those who have supported this research to completion.

\section{REFERENCES}

[1] Ministry of Home Affairs RI. "General Guidelines for dealing with the Covid-19 Pandemic for Regional Governments", [2020], Jakarta, Indonesia

[2] Indonesian Ministry of Health, "The Latest Situation of the Development of the Coronavirus (Covid-19)". Retrieved from Infeksi Emerging, Indonesian Ministry of Health. [2020], Jakarta, Indonesia

[3] Indonesian Ministry of Health. "Guidelines for preparing for Covid-19" [2020], Jakarta, Indonesia

[4] Ahmad Kholid, Health Promotion, Vol. 1, $1^{\text {st }}$ ed, Rajawali Pers, Jakarta, Indonesia, 2012

[5] Ahmad Kholid, Health Promotion, Vol. 1, $2^{\text {nd }}$ ed, Rajawali Pers, Jakarta, Indonesia, 2013

[6] AM Azam. Nexus Kedokteran Komunitas, "Relationship between Knowledge Level, Attitude towards Handwashing with Soap Behavior (CTPS) at SMPN 1 Surakarta and SMPN 6 Surakarta". Vol.5 No.2, pp 74-79 Desember 2016

[7] Amar, Rahma Yunita. Relationship between Knowledge and Habit of Washing Hands with Soap on Students of SD Negeri 101893 Bangun Rejo, Tanjung Morawa District. [2019]. Skripsi thesis, Universitas Islam Negeri Sumatera Utara, Medan, Indonesia.

[8] Anik Maryunani, Clean and Healthy Life Behavior, Vol. 1, $2^{\text {nd }}$ ed, Trans Info Media, Jakarta, Indonesia, 2013

[9] Anik Maryunani, Clean and Healthy Life Behavior, Vol. 1, $3^{\text {rd }}$ ed, Trans Info Media, Jakarta, Indonesia, 2015

[10] Arikunto, Research Procedure: A Practical Approach. Vol. 2, $2^{\text {nd }}$ ed, Rineka Cipta, Jakarta, Indonesia, 2013

[11] Arikunto, Research Procedure: A Practical Approach. Vol. 1, 1st ed, Rineka Cipta, Jakarta, Indonesia, 2013

[12] Atikah dan E. Rahmawati, Clean and Healthy Life Behavior, Vol. 2, $2^{\text {nd }}$ ed, Nuha Medika, Yogyakarta, Indonesia, 2012

[13] Audri Okta AWD, “Jurnal Promkes", “The Indonesian Journal of Health Promotion And Health Education”, vol 7 No. 1, pp 1-11 [2019] DOI : 10.20473/jpk.V7.11.2019.1-11

[14] Azwar, S. Human Attitude, Its Theory and Measurement. Vol. 1, 1 ${ }^{\text {st }}$ ed, Pustaka Pelajar Jogja Offset, Jogjakarta, Indonesia, 2013

[15] Budiono. Introduction to Public Health Education. Vol. 1, $1^{\text {st }}$ ed, Fakultas Kesehatan Masyarakat Universitas Diponegoro, Semarang, Indonesia, 2002

[16] Indonesian Ministry of Health. "Indonesia Health Profile 2009"., Departemen Kesehatan RI [2009], Jakarta.

[17] Machfoedz. I, Suryani. E, Sutrisno., Santoso. S. Health Education Part of Health Promotion. Vol. 2, $2^{\text {nd }}$ ed, Fitramaya, Yogyakarta , Indonesia, 2005

[18] Marimbi.. Growth and Development, Nutritional Status and Basic Immunization in Toddlers. Vol. 3, $2^{\text {nd }}$ ed, Nuha Medika, Yogyakarta, Indonesia, 2010

[19] Marimbi.. Growth and Development, Nutritional Status and Basic Immunization in Toddlers. Vol. 3, $3^{\text {rd }}$ ed, Nuha Medika, Yogyakarta, Indonesia, 2012

[20] Notoatmodjo, S., Health Behavioral Science. Vol. 1, $1^{\text {st }}$ ed,Rineka Cipta, Jakarta, Indonesia, 2010

[21] Notoatmodjo, S., Health Behavioral Science. Vol. 2, 2nd ed,Rineka Cipta, Jakarta, Indonesia, 2012

[22] Sastroasmoro, Sudigdo, Fundamentals of Clinical Research Methodology. Vol. 2, 2nd ed, Sagung Seto, Jakarta, Indonesia, 2014

[23] Sugiyono. Statistics For Research. Vol. 1, $1^{\text {st }}$ ed, Alfabeta, Bandung, Indonesia, 2005

[24] Sugiyono. Statistics For Research. Vol. 1, $2^{\text {nd }}$ ed, Alfabeta, Bandung, Indonesia, 2006

[25] Sugiyono. Statistics For Research. Vol. 1, $3^{\text {rd }}$ ed, Alfabeta, Bandung, Indonesia, 2007 